\title{
Competition and mimicry: the curious case of chaetae in brachiopods from the middle Cambrian Burgess Shale
}

Timothy P Topper ${ }^{1,2^{*}+}$, Luke C Strotz ${ }^{3+}$, Lars E Holmer ${ }^{1 \dagger}$, Zhifei Zhang ${ }^{4+}$, Noel N Tait ${ }^{3}$ and Jean-Bernard Caron ${ }^{5,6,7 \dagger}$

\begin{abstract}
Background: One of the first phyla to acquire biomineralized skeletal elements in the Cambrian, brachiopods represent a vital component in unraveling the early evolution and relationships of the Lophotrochozoa. Critical to improving our understanding of lophotrochozoans is the origin, evolution and function of unbiomineralized morphological features, in particular features such as chaetae that are shared between brachiopods and other lophotrochozoans but are poorly understood and rarely preserved. Micromitra burgessensis and Paterina zenobia from the middle Cambrian Burgess Shale are among the most remarkable examples of fossilized chaetae-bearing brachiopods. The form, functional morphology, evolutionary and ecological significance of their chaetae are studied herein.

Results: Like in Recent forms, the moveable but semi-rigid chaetae fringe both the dorsal and ventral mantle margins, but in terms of length, the chaetae of Burgess Shale taxa can exceed twice the maximum length of the shell from which it projects. This is unique amongst Recent and fossil brachiopod taxa and given their size, prominence and energy investment to the organism certainly had an important functional significance. Micromitra burgessensis individuals are preserved on hard skeletal elements, including conspecific shells, Tubulella and frequently on the spicules of the sponge Pirania muricata, providing direct evidence of an ecological association between two species. Morphological analysis and comparisons with fossil and extant brachiopod chaetae point to a number of potential functions, including sensory, defence, feeding, defouling, mimicry and spatial competition.

Conclusions: Our study indicates that it is feasible to link chaetae length to the lack of suitable substrate in the Burgess Shale environment and the increased intraspecific competition associated with this. Our results however, also lend support to the elongated chaetae as an example of Batesian mimicry, of the unpalatable sponge Pirania muricata. We also cannot discount brachiopod chaetae acting as a sensory grille, extending the tactile sensitivity of the mantle into the environment, as an early warning system to approaching predators.
\end{abstract}

Keywords: Micromitra, Paterina, Lagerstätten, Batesian mimicry, Setae, Polychaete, Lophotrochozoa

\section{Background}

Brachiopods are bivalved, lophophore-bearing lophotrochozoans that dominated the Palaeozoic benthic marine realm. With one of the most complete fossil records of any animal phylum [1], they were also one of the first organisms

\footnotetext{
* Correspondence: Timothy.Topper@nrm.se

${ }^{\dagger}$ Equal contributors

'Department of Earth Sciences, Palaeobiology, Uppsala University, Villavägen 16, SE - 75236 Uppsala, Sweden

${ }^{2}$ Department of Palaeobiology, Swedish Museum of Natural History, P.O. Box 50007, SE-104 05 Stockholm, Sweden

Full list of author information is available at the end of the article
}

to acquire biomineralized skeletal elements [1-3] and represent a vital component in unraveling the early evolution and relationships of the lophotrochozoa. The majority of fossil brachiopod taxa are known exclusively from their shells, with the preservation of distinctive unbiomineralized parts (including chaetae) typically restricted to Lagerstätte deposits, such as the lower Cambrian Chengjiang Lagerstätte [4] and the Burgess Shale Lagerstätte [5,6]. The rarity of preserved brachiopod unbiomineralized parts in the fossil record has hindered discussions regarding their early evolution and ecology, and the early evolution of the lophotrochozoa generally, largely due to disagreements about

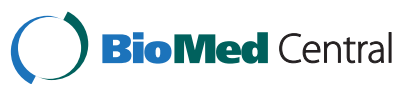


the interpretation of structures relative to extant phyla [7] and the apparent loss and development of key characters across groups [8]. For example, molecular studies have placed the Brachiopoda within the Trochozoa, closely related to the Nemertea, despite lacking a trochophore larval stage and possessing chaetae identical to annelids [8]. Only recently the chaetae of annelids and brachiopods were considered to be a homologous character [7]. Documentation of exquisitely preserved brachiopods including unbiomineralized features from Cambrian Lagerstätten, gives us a valuable window into the origins and functions of significant features that hold an evolutionary and functional importance in extant lophotrochozoan taxa.

Bristle or hair-like chitinous structures that project from the epidermis or exoskeleton are present across a range of lophotrochozoan organisms. Referred to as chaetae (also setae in the literature), these cuticular projections perform a range of sensory and locomotory tasks and are seen as a key character in phylogenetic analyses [9-11]. Perhaps the most well-known cuticular projections are the chaetae of the lophotrochozoan polychaete annelids. Annelid chaetae display a spectacular array of morphologies and are an important discriminator for species determination and phylogenetic placement in modern and fossil forms [11-14]. As a result, the chaetae in annelids have been intensely studied $[12,13,15]$. The same cannot be said for brachiopod chaetae. Brachiopod chaetae, in both fossil and extant taxa, do not show the same morphological variation seen in annelid chaetae and tend to be more simple, tapering, pointed forms [16-19]. Because they have not undergone the same intense examination as annelid chaetae, there exists a plethora of questions regarding their form, function, evolution and phylogenetic significance.

Adult brachiopod chaetae emerge from follicles along the dorsal and ventral mantle margins and occur in nearly all extant brachiopod groups, with the exception of craniid, megathyridid and the enigmatic cementing thecideidines [19-25]. Brachiopod chaetae have been recorded in multiple fossil brachiopod clades and in the vast majority of extant taxa $[4,26,27]$. This suggests that the possession of chaetae is likely a ubiquitous character in the Brachiopoda. It is potentially an ancestral feature and, like for other groups of lophotrochozoans $[12,13,19]$, holds both taxonomic and phylogenetic significance.

Studies of extant brachiopod chaetae have tended to focus on their ultrastructure, composition and development $[16-19,22,23,28]$ or on their use as part of larger scale phylogenetic analyses [10,11,29-31]. Despite their apparent morphological simplicity, a range of functions have been proposed for brachiopod chaetae $[19,21,32,33]$. The bundles of chaetae present in the lecithotrophic larval stage of Rhynchonelloids or Terebratelloids may be used for defence $[34,35]$, as part of a sensory complex $[19,21]$ or as a buoyancy aid, hindering the larvae from sinking in the water column [19]. The chaetae in adult brachiopods have been suggested as functioning as sensory grilles [21,32], assisting in the creation of currents for feeding purposes [21,33], sieving of inhalant currents [24,36,37], protection [37], burrowing [38] and as a deterrent in competition for space in intertidal zones [34]. Many of these functional interpretations remain to be rigorously tested and none have taken fossil taxa into account, despite Recent brachiopods, in terms of diversity, representing only a small fraction of what was a much larger clade in the Palaeozoic [24].

Walcott's [39,40] documentation of Micromitra from the Burgess Shale Lagerstätte in western Canada represents the first report of brachiopod chaetae in the fossil record. Arguably the most significant and influential of the Cambrian Lagerstätten, the brachiopods from the Burgess Shale have seen little attention since these original descriptions [5,6,39-42]. Here, we examine one of the more remarkably preserved brachiopods from the middle (Series 3, Stage 5) Cambrian Burgess Shale, Micromitra burgessensis Resser [41]. Micromitra is exceptionally preserved, exhibiting elongate chaetae that fringe the mantle and extend far beyond the margin of the biomineralized shell (Figures 1,2 and 3A-E). The shape, size and frequency of the chaetae possessed by $M$. burgessensis are unique amongst extant and fossil brachiopod taxa and herein we provide explanations for their functional significance based upon comparisons with extant brachiopod chaetae and chaetae of other lophotrochozan groups. Specimens of a second brachiopod taxon, Paterina zenobia Walcott, [40] are also discussed, as a number of specimens exist with preserved chaetae (Figures 3E and 4). The function of chaetae in fossil brachiopod taxa is perhaps even more difficult to assess than for extant forms, yet as chaetae represent such a distinctive morphological feature for both $M$. burgessensis and $P$. zenobia, their potential function demand attention. Both Micromitra and Paterina are globally distributed genera across Cambrian Series 2-3 $[43,44]$ and their taxonomic position in one of the oldest brachiopod families (the Paterinata) provides important clues about the evolution, ecological and phylogenetic significance of lophotrochozoan chaetae.

\section{Results}

\section{Micromitra burgessensis}

Micromitra burgessensis can be readily identified in the Burgess Shale Formation from its distinctive diamondshape ornament (Figures 1 and 2). The valves of M. burgessensis reach a maximum width of $12.1 \mathrm{~mm}$ and a maximum length of $10 \mathrm{~mm}$. Specimens (58 individuals) 


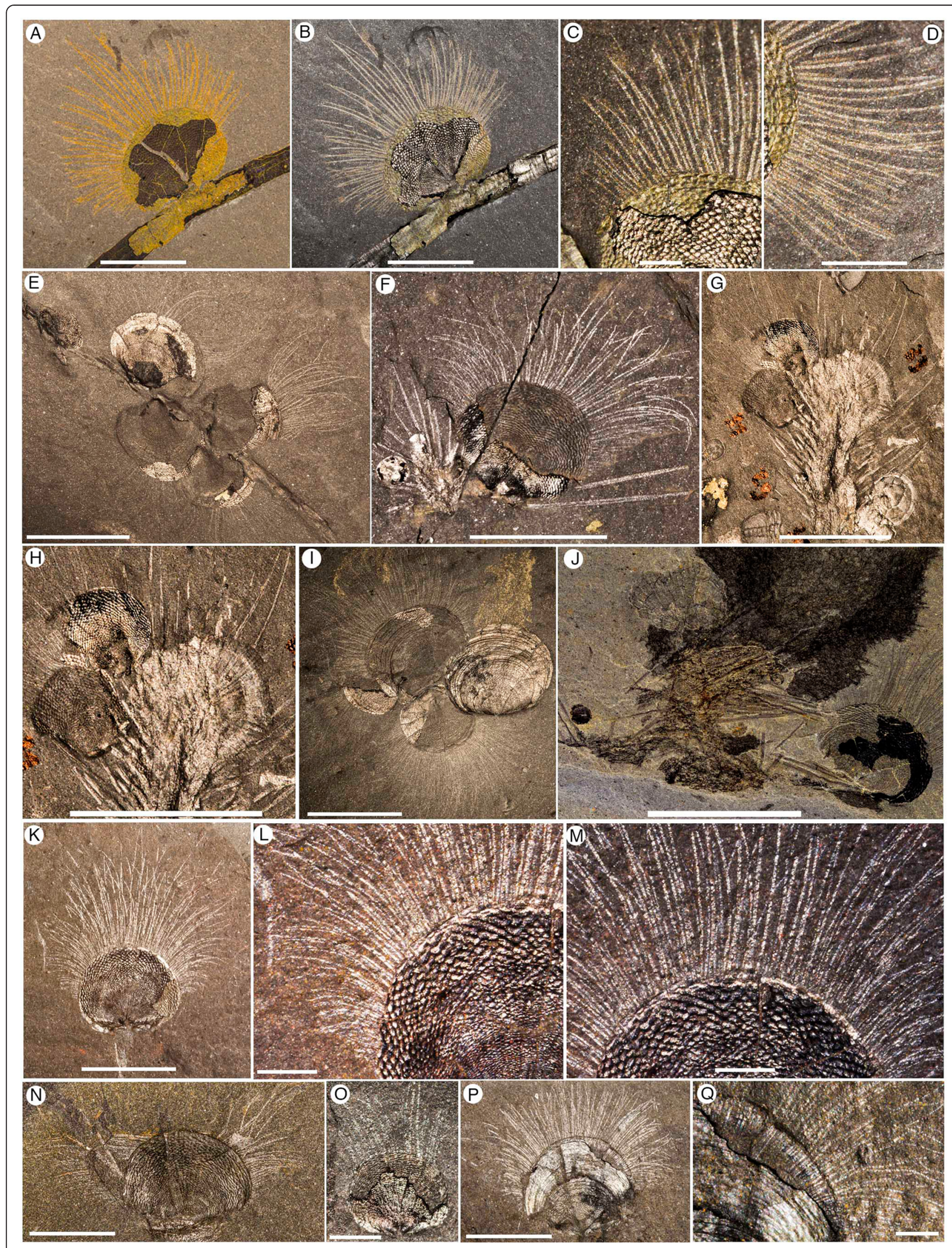

Figure 1 (See legend on next page.) 
(See figure on previous page.)

Figure 1 Micromitra burgessensis from the middle (Series 3, Stage 5) Cambrian Burgess Shale. A-D, ROM63169, RQ + 8.2 m. A-B, Plan view of specimen attached to Tubulella; C-D, Close up anteromedial and posterolateral chaetae, scale bar $1 \mathrm{~mm}$. E, ROM63170, RQ + 8.2 m, Plan view of specimens attached to Tubulella, scale bar 10 mm. F, USNM 59801a, Walcott Quarry, Phyllopod Bed, Plan view of Acrothyra and Micromitra attached to Pirania. G-H, ROM57839.30-33, BW-150 cm. G, Plan view of Nisusia and Micromitra attached to Pirania, scale bar $10 \mathrm{~mm}$. H, Close up of specimens attached to Pirania, scale bar $10 \mathrm{~mm}$. I, ROM63171, RQ + $11.4 \mathrm{~m}$, Plan view of a cluster of Micromitra specimens, scale bar $10 \mathrm{~mm}$. J, ROM56248, BW-100 cm, Plan view of Micromitra, Nisusia and Acrothyra attached to Pirania, scale bar 10 mm. K-M, USNM 59801a, Walcott Quarry, Phyllopod Bed. K, Plan view. L, Close up of posterolateral chaetae, scale bar $1 \mathrm{~mm}$. M, Close up of anteromedial chaetae, scale bar $1 \mathrm{~mm}$. N, ROM63172, BW-210 cm, Micromitra with swept chaetae. O, ROM63173, BW-210 cm, juvenile Micromitra specimen, scale bar 1 mm. P-Q, ROM63174, BW-235 cm. P, Plan view; Q, Close up of chaetae beneath shell, scale bar $1 \mathrm{~mm}$. Scale bars $5 \mathrm{~mm}$ unless otherwise stated.

are commonly found attached to a variety of substrates, most commonly (32 out of 58 individuals) on the spicules of the sponge Pirania (Figures 1F-J and 2J-M) but also on Tubulella (Figure 1A-E) and on other individuals of M. burgessensis (Figures 1I and 2C). Of the 208 specimens of $M$. burgessensis examined from the Burgess Shale Formation, a total of 101 (48\%) individuals were preserved exhibiting identifiable chaetae. The chaetae fringe the dorsal and ventral valve margins and are generally at their greatest length anteromedially, decreasing in length posterolaterally as they approach the hinge line, where they disappear entirely (Figures 1 and 2). The individual chaeta are elongate and taper to a pointed terminus. The chaetae are evenly distributed across the margin of the shell giving the brachiopods a rough bilateral symmetrical appearance. Commonly curved, but never twisted, the chaetae radiate out from the valve margins and probably possessed a degree of flexibility in life. Evidence from broken chaetae (Figure 2D) however, suggests that the chitinous structures, despite their flexibility, possessed some degree of rigidity and brittleness. The presence of dissociated valves that have preserved chaetae suggests the chaetae decay at a slower rate than the muscles that hold the two valves together (Figure 2I). The chaetae can be seen emerging from underneath the shell in specimens where the shell margins are broken (Figures 1Q, 2B and 3D), however no additional internal soft tissue (e.g. mantle, lophophore) has been observed.

The total number of chaetae and spacing between each chaeta as they emerge from the valve margin of individuals is variable and difficult to measure accurately since the chaetae associated with one or both of the valves may be variably preserved (compare Figures $1 \mathrm{~K}-\mathrm{M}$ and $2 \mathrm{~N}-\mathrm{R}$ with Figures $2 \mathrm{~A}-\mathrm{B}$ ). Specimens that possess chaetae that are spaced at approximately $60-80 \mu \mathrm{m}$ intervals, with a maximum number of 84 chaetae, are interpreted as representing specimens where chaetae associated with only one valve is preserved. Specimens that possess chaetae that are spaced at approximately $20-50 \mu \mathrm{m}$ intervals, with a maximum total number of 144 chaetae, are interpreted as representing specimens where the chaetae associated with both ventral and dorsal valves are preserved on the same surface. The chaetae of $M$. burgessensis, in respect to shell size are remarkably long (maximum length $11.7 \mathrm{~mm}$ ). On average, the maximum chaetal length is the same length of the shell from which it projects $(102 \%$ of shell length, $n=30)$ but can in rare circumstances exceed twice the maximum length of the shell. The posterolateral chaetae are usually shorter than their anteriomedial counterparts and typically measure close to half the width of the brachiopod shell (maximum length $6 \mathrm{~mm}$ ). With both posterolateral sides taken into account, this can double the width of the entire brachiopod specimen. Individual chaeta vary in width from 67 to $100 \mu \mathrm{m}$ (mean $81 \mu \mathrm{m}, \mathrm{n}=50$ ) and show a tendency to become thinner on the posterolateral sides of the valve. A small individual, interpreted as representing a juvenile (width of $2 \mathrm{~mm}$, length of $1.75 \mathrm{~mm}$, Figure 1O) also possesses chaetae. The chaeta in this case are $1.5 \mathrm{~mm}$ in length $(85 \%$ of the shell length) and fewer in number (total number of chaetae 36). No chaetal ultrastructure is obvious from the specimens examined.

\section{Paterina zenobia}

Paterina zenobia broadly resembles Micromitra burgessensis in general shell morphology and was originally assigned to Micromitra [40], however the differences in ornament (prominent growth lines versus diamond shaped ornament) differentiate the two taxa. Paterina zenobia is only known from talus material and despite being found in material overlying the Walcott Quarry (presumably derived from the younger Raymond Quarry Member), the species has yet to be identified in situ. Seventy four specimens of $P$. zenobia were examined, of which 19 (26\%) were preserved exhibiting identifiable chaetae. The valves of $P$. zenobia are slightly larger than $M$. burgessensis, reaching a maximum of $15 \mathrm{~mm}$ in width and $14 \mathrm{~mm}$ in length and like M. burgessensis are found attached to a variety of substrates, such as trilobite carapaces (Figure 4A-C) and other individuals of P. zenobia. The chaetae in the majority of these specimens were not complete and measurements and counts were possible for only five individuals (Figure 4). One specimen of $P$. zenobia is preserved attached to Pirania, however no identifiable chaetae are apparent. 


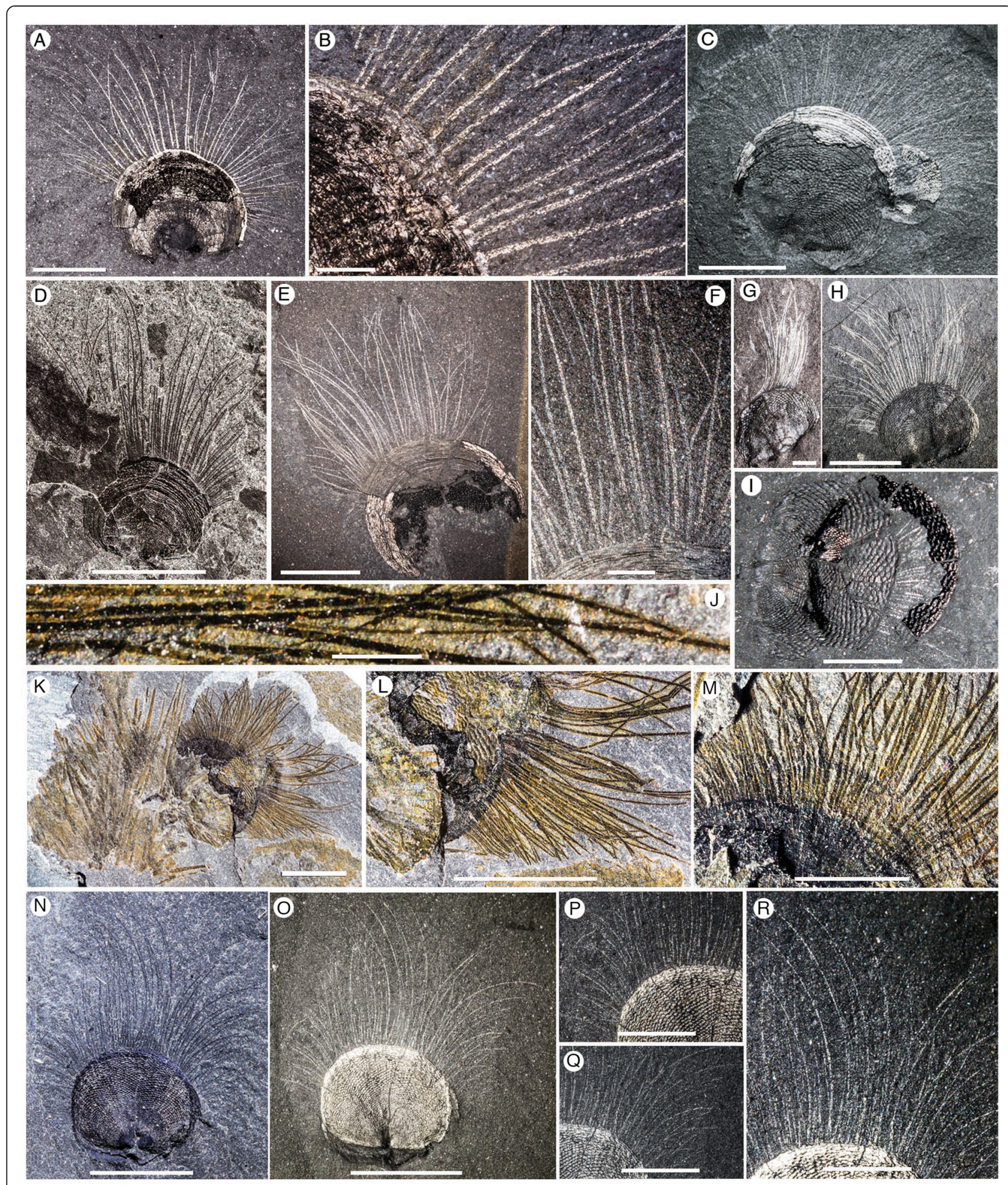

Figure 2 (See legend on next page.) 
(See figure on previous page.)

Figure 2 Micromitra burgessensis from the middle (Series 3, Stage 5) Cambrian Burgess Shale. A-B, USNM 69646, Walcott Quarry, Phyllopod Bed. A, Plan view. B, Close up of anteromedial chaetae, scale bar $1 \mathrm{~mm}$ C, ROM63175, RQ + 8.1 m, Plan view. D, ROM57603, BW-120 cm, Plan view. E-F, ROM63176, RQ + 8.2 m. E, Plan view. F, Close up of anteromedial chaetae, scale bar 1 mm. G, ROM63177, BW-235 cm, Micromitra with swept chaetae, scale bar 1 mm. H, ROM63178, WT talus. Plan view. I, ROM57597, BW-235, Dissociated valves with chaetae preserved, scale bar 2.5 mm. J-M, ROM63180, WQ + 30. J, Close up of anteromedial chaetae, scale bar 1 mm. K, Plan view of Micromitra attached to Pirania. L, Close up of posterolateral chaetae. M, Close up of anteromedial chaetae, scale bar $2.5 \mathrm{~mm}$. N-R, ROM63181, RQ + 8.4 m. N-0, Plan views. $\mathbf{P}-\mathbf{Q}$, Close up of chaetae, scale bars $2.5 \mathrm{~mm}$. $\mathbf{R}$, Close up of anteromedial chaetae, scale bars $2.5 \mathrm{~mm}$. Scale bars $5 \mathrm{~mm}$ unless

otherwise stated.

The chaetae of $P$. zenobia bear many similarities to those of $M$. burgessensis, fringing the valve margins and are at their greatest length anteromedially, decreasing in length posterolaterally as they approach the hinge line, where once again they disappear entirely (Figure 4 ). The chaetae are elongate and taper to a point and their curved and swept nature also suggests a degree of flexibility in life (Figure 4A). The chaetae are not as long as observed in $M$. burgessensis, reaching a maximum length of $7.1 \mathrm{~mm}(67 \%$ of shell length), and on average $(\mathrm{n}=5)$ only extend approximately $55 \%$ of the entire shell length (Figure 4). The posterolateral chaetae also extend the width of the individual by up to $7 \mathrm{~mm}$ (3.5 mm on each posterolateral side), an increase in the width of the individual of $70 \%$ (Figure 4A). Individual chaeta varies in width from 77 to $114 \mu \mathrm{m}$ (mean $99 \mu \mathrm{m}, \mathrm{n}$ $=50$ ) and decrease slightly in width on the posterolateral sides of the valve. The total number of chaetae for each individual is problematic as parts of the shell on many specimens (Figure 4) are obscured or damaged, leaving an incomplete margin. For all chaetae-bearing individuals it is interpreted that the chaetae from both the ventral and dorsal valves are visible. The most complete specimen (ROM63182; Figure 4A) possesses approximately 175 chaetae, spaced at intervals of $20-40 \mu \mathrm{m}$. The remaining individuals exhibited a range of 122 to 146 chaetae, spaced at similar $20-40 \mu \mathrm{m}$ intervals, however it is assumed that a number of chaetae are not preserved, since the shell margin is incomplete (Figure 4). No juveniles of P. zenobia possessing chaetae have been observed.

\section{Discussion}

\section{Functions and mechanisms of chaetae}

The chaetae of Micromitra burgessensis and Paterina zenobia contrast significantly with those of extant

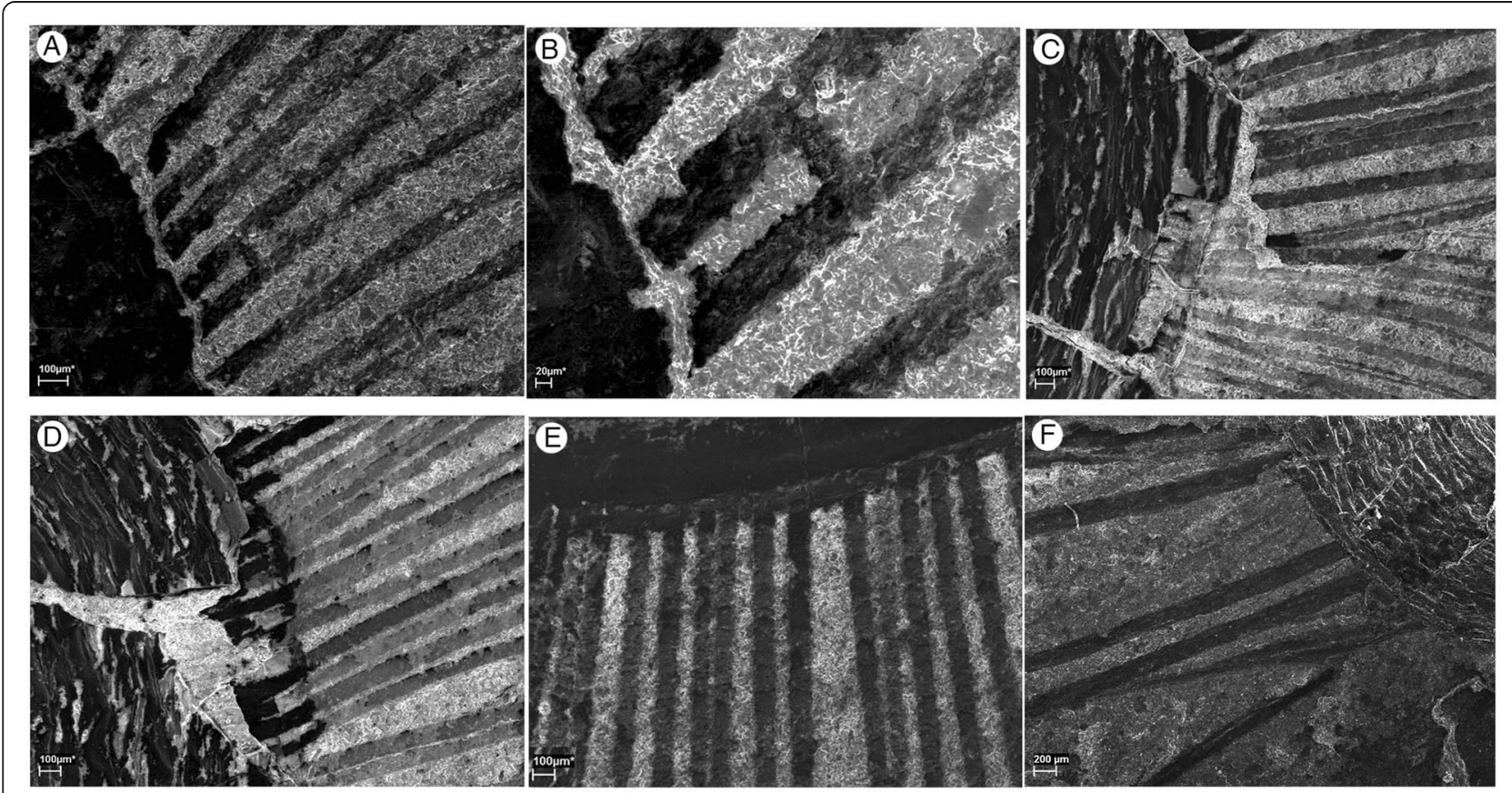

Figure 3 Scanning Electron Microscope images of brachiopods from the middle (Series 3, Stage 5) Cambrian Burgess Shale. A-B, ROM63169, RQ + 8.2 m, anteromedial chaetae of Micromitra burgessensis, B, scale bar 20 mm. C-D, ROM57603, BW-120 cm, anteromedial chaetae of Micromitra burgessensis. E, ROM63185, Talus above Walcott Quarry, anteromedial chaetae of Paterina zenobia. F, GSC 81224, Walcott Quarry, Phyllopod Bed, Pirania muricata spicules emerging from underneath Micromitra burgessensis, scale bar $200 \mu \mathrm{m}$. Scale bars $100 \mu \mathrm{m}$ unless otherwise stated. 


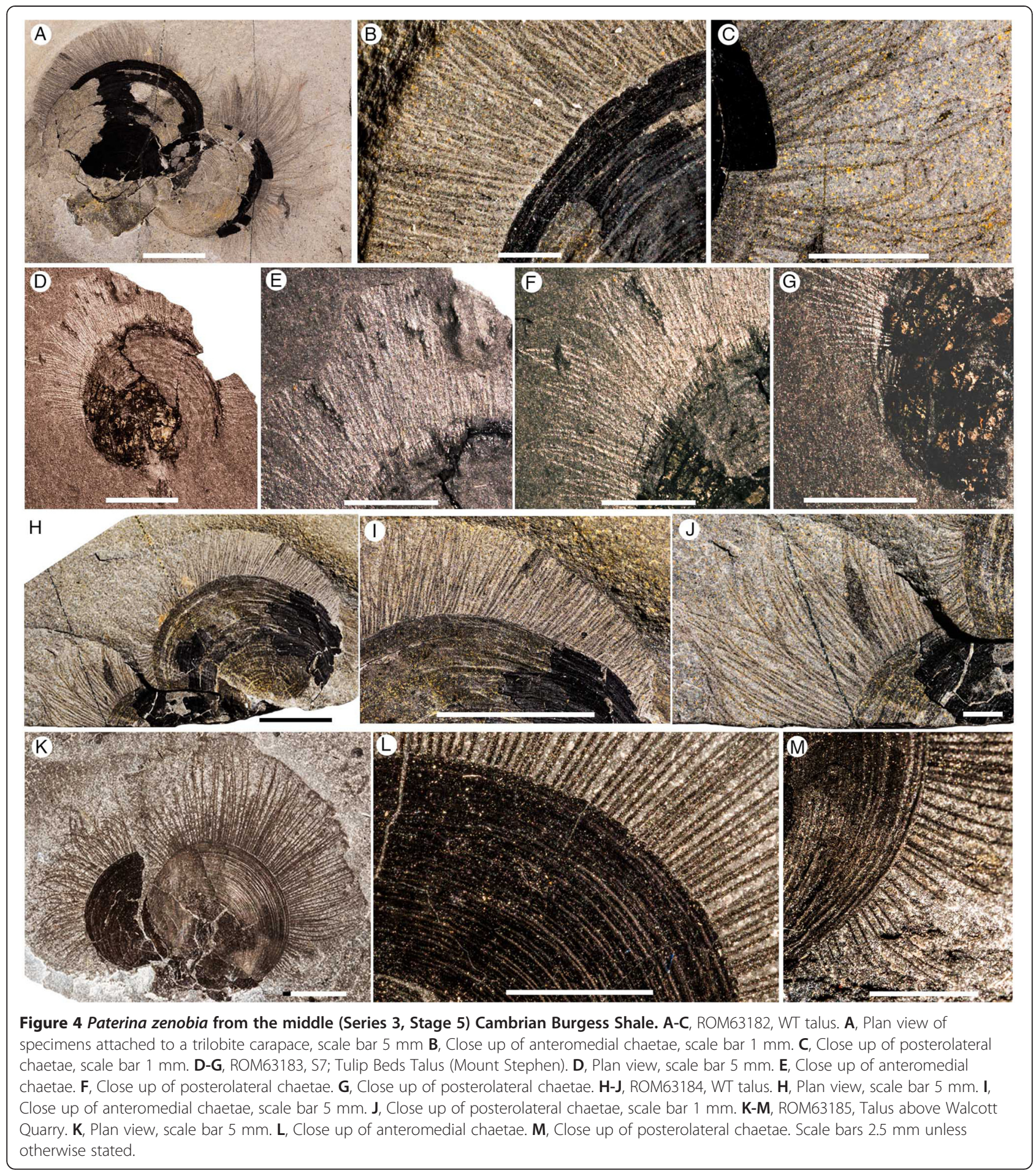

brachiopods. For example, the average diameter of $M$. burgessensis and P. zenobia chaetae are $81 \mu \mathrm{m}$ and $99 \mu \mathrm{m}$ respectively, compared with the chaetae of extant taxa, such as Discinisca strigata (Figure 5A-B), that measure $13 \mu \mathrm{m}$ in diameter [33] and the chaetae of Lingula anatina that are approximately $14 \mu \mathrm{m}$ in diameter (Lüter [19], Figure one). This is despite the comparable shell size of all these taxa. The chaetae possessed by $M$. burgessensis and $P$. zenobia also reach a greater length relative to shell size when compared to the majority of extant taxa. Only the chaetae of discinids are comparable (Figure 5A-B), extending approximately $80 \%$ of their maximum shell length $[33,45]$. Given their size and prominence, it is certain that the chaetae of 


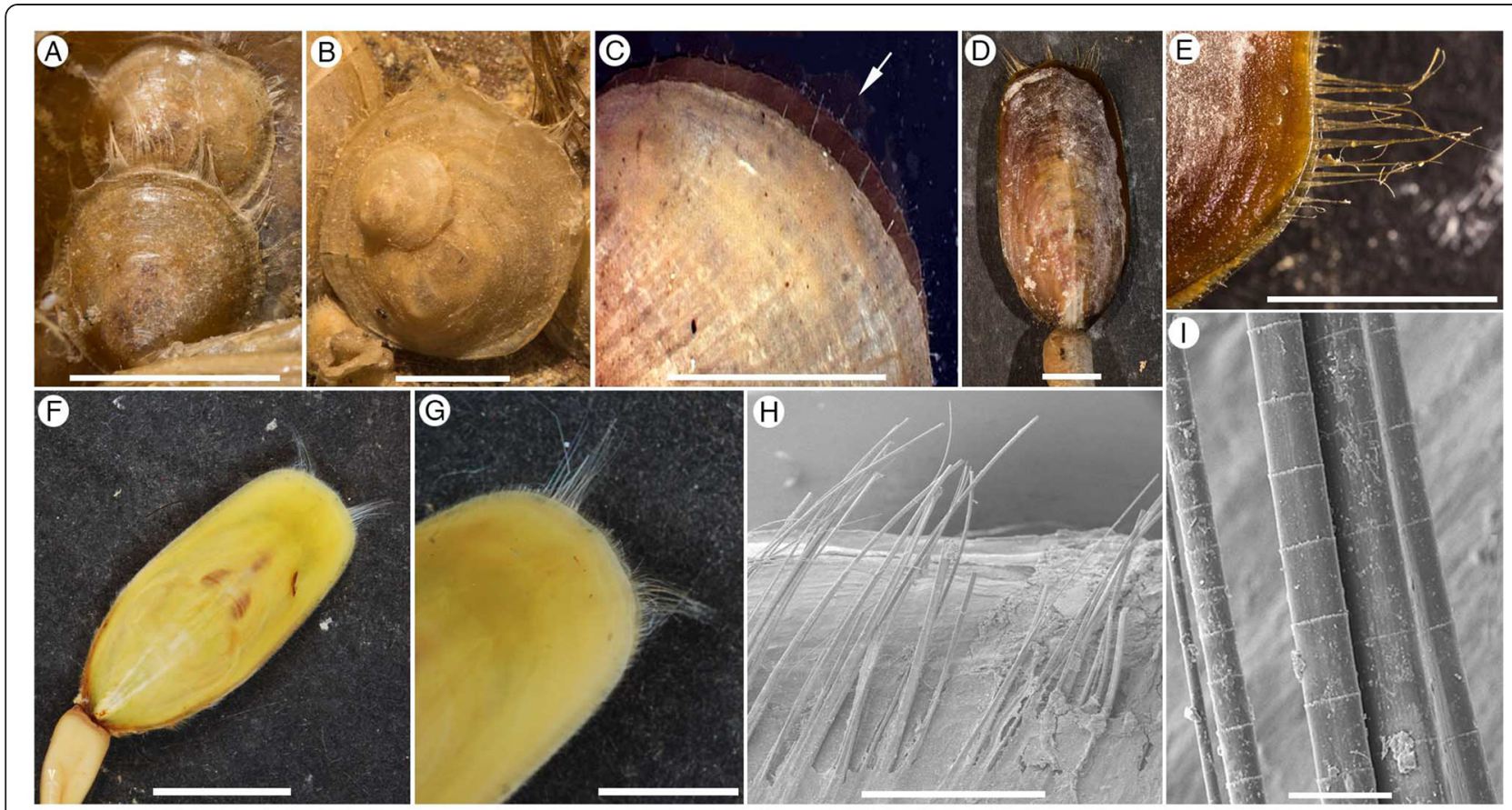

Figure 5 Extant brachiopod genera. A-B, Discinisca lamellosa, Namibia. A, SMNH141416, Gregarious cluster of individuals exhibiting chaetae. B, SMNH141417, Gregarious cluster of individuals exhibiting chaetae.C, Terebratulina retusa, west coast of Sweden, Arrow directed towards marginal chaetae. D-E, Lingula adamsi, SMNH141418, Beidaine, Hebei Province, China. D, Plan view, scale bar $1 \mathrm{~cm}$. E, Close up of anterolateral chaetae. F-I, Lingula anatina, F-G, SMNH 140566, Ariake Bay, Japan. F, Plan view, scale bar 1 cm. G, close up of anterior chaetae. H-I, SMNH141419, Cebu Island, Philippines. $\mathbf{H}$, Anterior chaetae, scale bar $1 \mathrm{~mm}$. I, Magnification of chaetae, scale bar $50 \mu \mathrm{m}$. Scale bars $5 \mathrm{~mm}$ unless otherwise stated.

both $M$. burgessensis and P. zenobia have important functional significance. Their construction would represent a significant investment to the organism. They also represent a potential liability, extending well beyond the shell margin, their size potentially inhibiting the tight closure of the valves and thus increasing the vulnerability of the individual to predators. Based upon a comprehensive review of the Burgess Shale fauna, both fossil and extant brachiopods and similar structures in other organisms, we herein propose and provide evidence for and against a number of potential functions for chaetae in $M$. burgessensis and $P$. zenobia These functions are: sensory and defence; feeding and defouling; mimicry and spatial competition.

\section{Sensory function}

Brachiopod chaetae are frequently interpreted as sensory grilles, extending the tactile sensitivity of the mantle beyond the margin of the valves by projecting their chitinous chaetae into the environment $[21,25,32,46]$. Despite this generally accepted sensory role for brachiopod chaetae, it has never been critically evaluated and very little is known about how chaetae function as sensory features in living brachiopods [25]. A response to some form of tactile stimuli is one option, the long projections acting as an early warning system when stimulated by potential predators. Living brachiopods most certainly respond to tactile stimuli, but the chaetae do not appear to have any direct connection to the nervous system [25] and no specialized sensory chaetal cells have been identified [25,32]. The mantle edges of living brachiopods are richly supplied with nerves, and any tactile stimulus or chemical imbalance at the mantle edge causes an immediate and rapid closure of the shell $[32,46,47]$. This appears to be the primary protective reaction in living brachiopods, the closure of the shell protecting the soft-tissue from potentially harmful agents in the external environment [32]. There currently exists no published evidence that protective sealing of the shell is directly linked to the stimulation of the brachiopod chaetae, only to the mantle edge itself. As projections of the mantle, movement of the chaetae presumably stimulate sensory organs within the mantle, however no research in extant taxa, exists to confirm this.

Whilst the sensory effectiveness of brachiopod chaetae is questionable, it is possible the long, closely-spaced, somewhat rigid chaetae of Micromitra burgessensis and Paterina zenobia may have constituted a protective grille, inhibiting access to the mantle tissues. The unusual length and thickness (compared to Modern forms, see Figure 5) and high density of chaetae would severely impede the potential predator, regardless of whether the valves could shut completely. The potential effectiveness of this protective grille may explain the lack of durophagy 
on the shell edge of $M$. burgessensis and P. zenobia individuals, as documented in other Cambrian deposits [48-50]. Brachiopods have been documented in the gut of Ottoia prolifica [51-53] a priapulid worm, and the large arthropod, Sidneyia inexpectans [52,54] and possibly the only effective method of predation on brachiopods was the entire digestion of the brachiopod individual as seen in Ottoia [51] or the grasping and crushing of the individual into ingestible fragments as seen in Sidneyia [52]. For both these modes of feeding, any early warning system provided by the chaetae, and the associated closure of the valves, may have been an inadequate protective reaction. Another possibility is that the substantial increase in body size of chaetae-bearing brachiopod individuals was a deterrent against predators. The illustrated $M$. burgessensis individuals in the gut of Ottoia [51] are all relatively small (approximately 2-3 $\mathrm{mm}$ in width) and the possession of long, semi-rigid chaetae may have made the task of ingesting the larger brachiopod prey mechanically difficult for Ottoia. The fragmented nature of M. burgessensis valves in the gut of Sidneyia [52] prevents a corresponding measurement.

Brachiopods were certainly prey items in the Burgess Shale community however the low percentage of brachiopod individuals in examined gut contents and coprolites [51,52] may reflect the effectiveness of the chaetae as sensory tools. The exaggerated length of the chaetae in $M$. burgessensis and P. zenobia would have potentially provided an earlier warning system in comparison to much shorter marginal chaetae (Figure 5C), allowing sufficient time to close their shells and increasing their chance of survival. Direct evidence of durophagous predation, whether represented by boreholes, drillholes or shell-breaking bite marks is rare in brachiopod specimens from the Burgess Shale. A similar story is reported from the Chengiiang Lagerstätte, where there are no recognized examples of durophagous activities [48] and brachiopods are also conspicuously absent from early Cambrian coprolite aggregates [49]. Repaired durophagus shell damage has been recorded in brachiopods from the Cambrian Wulongqing Formation (Series 2, Stage 4) of China, although only thirteen specimens of Diandongia pista [55] out of over 1400 specimens in total are documented with predatory shell damages [48]. This apparent lack of predation on individuals suggests that, brachiopods possessed excellent defensive mechanisms against predators.

Ideally, any effective defense system would see the sensitive mantle edges projected not only outwards, but also dorsally and ventrally from the apertures, covering the entire shell margin to protect from harmful agents approaching the individual from every direction. It would be difficult to reconcile this morphological specification with the structural requirement for protection, which is the tight sealing of the valves. Additionally, the large majority of extant brachiopods, such as the lingulids [21] can retract their chaetae back into their shell, allowing their shells to securely close, protecting the soft tissue. The sheer length, number of chaetae present and their semi-rigidity suggests that, for $M$. burgessensis and $P$. zenobia, chaetal retraction would not be possible, resulting in incomplete closure of the valves and potentially weakening their primary defensive system. The large majority of other shell bearing lophotrochozoans, such as bivalves and gastropods, possess the ability to fully enclose their soft parts within their protective shell [56]. Individuals with an open gape would likely be much more susceptible to predation, with likely lower fitness compared to individuals that could tightly close their shell. Consequently such individuals are rare in modern marine communities.

The possibility also exists that the low percentage of brachiopods in predator gut contents may indicate that brachiopods were rarely chosen as prey. Many authors consider brachiopods, both in the current marine realm and in the geological past, as not having been significant prey items [32,57-61]. This is predominantly due to the lack of detailed studies on living and fossil taxa and laboratory observations that show a variety of modern predators (e.g. fish, gastropods and asteroids) actively preferring bivalve mussels over brachiopods [57] or avoiding brachiopod individuals altogether [58]. Nevertheless, there are records of predation on Recent brachiopods $[62,63]$ and despite the tenuous evidence from Cambrian Lagerstätte deposits, there are have been intermittent accounts of predation on brachiopods throughout the Palaeozoic $[50,61,64,65]$. Brachiopods were faced with predation pressure during the Cambrian and certainly in the Burgess Shale, however with the exception of Ottoia and Sidneyia, direct evidence of other brachiopod predators in the Burgess Shale is meager. It is also difficult to rationalize, that if the unique length of $M$. burgessensis and P. zenobia chaetae evolved as effective sensory tools against predation, why haven't similar sized structures been employed in a similar manner by subsequent brachiopod lineages?

\section{Feeding and modifying flow}

Activity in sessile, attached brachiopods is essentially restricted to the opening and closing of the valves and the near-continual beating of the lateral cilia of the lophophore, allowing the organism to feed by bringing in various nutritional sources from the water $[32,66]$. Living brachiopods have been observed to be quite selective in the capturing of particles for ingestion and have the ability to reject unwanted excess mud and silt from the lophophore and mantle cavity by reversing the direction of the lophophore ciliary beat [67-70]. Spines 
and chaetae have previously been suggested as acting as a feeding sieve, forming interlocking grilles around the commissural gape, ensuring effective sieving of inhalant currents and protection against larger less desirable particles $[32,37]$. Protection against larger particles would not have been necessary for the benthic Burgess Shale community that predominantly lived on a homogeneous fine-grained mud seafloor [71,72]. A fine-grained muddy seafloor would, however, have increased the likelihood of 'clogging' the brachiopod lophophore with the accumulation of suspended fine particles in the mantle cavity, leading to an inability to either intake food or respire or both, and ultimately leading to the death of the organism. The possibility therefore exists that the chaetae of Micromitra burgessensis and Paterina zenobia represent a mechanism to obstruct the excessive intake of fine particles.

Chaetae in specimens of $M$. burgessensis are spaced at approximately $20-50 \mu \mathrm{m}$ and $20-40 \mu \mathrm{m}$ in P. zenobia. This measurement was taken at the anterior shell margin, and is interpreted as representing the chaetae from both dorsal and ventral valves, signifying that the valves are preserved closed. Space between the chaetae would have increased upon the opening of the valves. With petrographic analyses indicating that particles in the Burgess Shale claystones were originally probably less than $25 \mu \mathrm{m}$ [72], the chaetae of M. burgessensis and $P$. zenobia would not have acted as an effective screening tool for limiting the amount of fine particulate matter entering the mantle and the clogging of the lophophore. The open gape of the extant genera, Terebratalia and Liothyrella is frequently held at the maximum angle that can be covered by the projecting chaetae, an action that has been used to support the interpretation of the chaetae acting as a grill or strainer to keep out sediment and other large particles from the mantle cavity [32,69]. The chaetae of Terebratalia and Liothyrella however are short relative to shell size, approximately $20 \%$ of shell length $[69,73]$. Such an action would not be physically possible in M. burgessensis or P. zenobia, as this would require the individual to have an open gape twice the length of its valves. The lophophore of a paterinid brachiopod has never been documented, however previous authors have suggested the removal of unwanted fine particles from the mantle cavity of extant brachiopods is likely to be reliant on the lophophore [69] and not dependent on chaetae.

Some extant brachiopods utilize their chaetae to form siphons to either assist in feeding [33,45] or burrowing into the substrate [21,38]. For example, the anterior chaetae of Discinisca strigata [74] bear fine lateral processes which mechanically interlock forming an incurrent siphon that extends above the substratum and other nearby epifauna, allowing for an enhanced current and improvement in feeding $[33,45]$. With both species of paterinid Burgess Shale brachiopod species documented attached to a variety of substrates, utilizing their chaetae to assist in a burrowing process can be discounted. Neither $M$. burgessensis nor $P$. zenobia show a comparable chaetal clustering to Discinisca (Figure 5AB) and, consequently, it is unlikely that their chaetae were used to form a siphon. As many M. burgessensis specimens are attached to the sponge Pirania muricata in the Burgess Shale ecosystem (56\% of attached $M$. burgessensis specimens), a siphon to enhance current for feeding purposes may not have been necessary, as $M$. burgessensis individuals could have taken advantage of nutrients, through currents, however small, produced by the sponge $[75,76]$.

\section{Mimicry}

Mimicry is commonly thought to involve the resemblance of one organism (described as the mimic) to another organism (described as the model), the physical similarity adopted by the mimic, a mechanism to deceive a third organism [77-79]. Harmless and palatable organisms frequently mimic, dangerous and/or unpalatable organisms to avoid interest from potential predators, a form known as Batesian mimicry [78-82]. Mimicry has been interpreted across a range of marine lophotrochozoa taxa, including polychaetes [78], chaetognaths [78] and a variety of molluscs $[79,83]$. Mimicry, as a concept, has rarely been applied to brachiopods and many of the previous examples possibly represent homeomorphy or camouflage rather than mimicry [84]. A major hurdle in understanding mimicry is that it is notoriously hard to detect, even in extant faunas, as evidence for mimicry is predominantly a result of direct observation of the organisms in question [77,85-88].

Micromitra burgessensis and Paterina zenobia are preserved in the Burgess Shale Formation attached to a variety of substrates, including the demosponge Vauxia, the enigmatic Chancelloria, a variety of disarticulated skeletal elements and conspecific individuals (Additional file 1). The majority of chaetae-bearing $M$. burgessensis specimens (56\% of attached individuals) are preserved perched on the cactus-like sponge, Pirania muricata [89]. Pirania is characterized by distinctive coarse, long monaxial spicules [90], that radiate upward and outward from the branch of the moderately thick-walled sponge (Figure 6B-D). It is these long spicules to which Micromitra individuals commonly attach to (Figures 1G, 2K and 6D-E). Paterina zenobia specimens are preserved attached to Pirania muricata (12.5\% of attached individuals), however the lack of in situ material, limits further detailed ecological comparisons and studies.

Pirania muricata is interpreted as representing an unpalatable organism to the majority of predators, their 


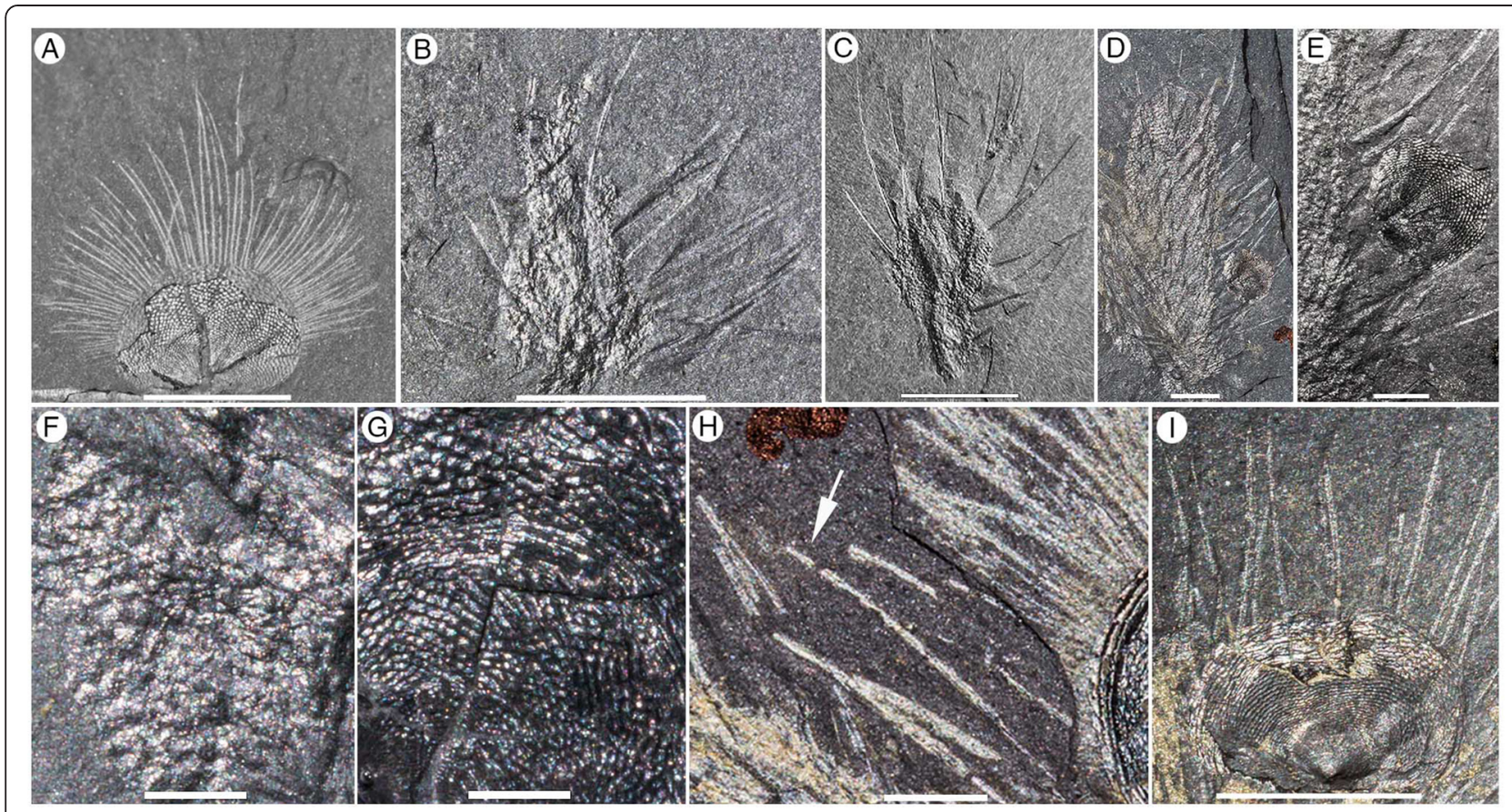

Figure 6 Micromitra burgessensis and Pirania muricata from the middle (Series 3, Stage 5) Cambrian Burgess Shale. A, ROM63169, RQ + $8.2 \mathrm{~m}$, plan view of M. burgessensis. B, ROM63186, BW-210 cm, Plan view of P. muricata. C, ROM63188, BW- $210 \mathrm{~cm}$, Plan view of $P$. muricata. D-E, ROM63189, BW-170 cm. D, Plan view of $P$. muricata and M. burgessensis, scale bar $2 \mathrm{~mm}$. E, close up of M. burgessensis and the sponge wall of $P$. muricata, scale bar $1 \mathrm{~mm}$. F-G, ROM61135, BW-200 cm. F, Close up of rhomboidal texture of the sponge wall of $P$. muricata, scale bar $1 \mathrm{~mm}$. G, Close up of shell ornament on M. burgessensis, scale bar $1 \mathrm{~mm}$. H, ROM63187, WQ-170 cm, Close up of P. muricata spicules (arrow is used to indicate sponge spicules on the left of the image) juxtaposed with M. burgessensis chaetae (right of the image), scale bar 1 mm. I, GSC 81224 , Walcott Quarry, Phyllopod Bed, Plan view of M. burgessensis with P. muricata spicules emerging from underneath the shell. Scale bars $5 \mathrm{~mm}$ unless otherwise stated.

siliceous skeleton offering low nutritional value, analogous to modern siliceous sponges [91]. The lack of predation marks on Pirania specimens and the lack of Pirania spicules in the contents of guts or coprolites $[49,51]$ support this interpretation. Spongivory in modern communities is largely restricted to a few species of fish [92], nudibranchs [93] and turtles [94,95] all absent from Cambrian faunas. Pirania though, may not be totally immune from predators, with claims that lobopodians, such as Aysheaia and Hallucigenia fed on sponges in the Burgess Shale community [96]. This suggestion is largely hypothetical and based entirely on ecological associations [96]. Recent investigation of gut contents in lobopodians from Chengjiang and the Burgess Shale Lagerstätten [97] provided no evidence to support this theory and sponge spicules have not been reported from the gut contents of either Ottoia or Sidneyia [51,52]. It is conceivable that the long, monaxial spicules possessed by Pirania are defensive structures, offering protection from potential predators. Similar structures however, have also been interpreted as offering body support for erect sponges [98]. There is currently no direct evidence to suggest high rates of predation in Pirania and brachiopods were likely more frequently predated upon and seen as a more palatable prey item in the Burgess Shale ecosystem.

The individual radiating spicules of Pirania typically measure 7-8 $\mathrm{mm}$ in length, are approximately 100$200 \mu \mathrm{m}$ in width (Figure 3F) at the base of the spicule and taper to a point [90]. These dimensions are very similar to the length and width of chaeta possessed by M. burgessensis. The similarities are further apparent in samples where $M$. burgessensis valves are preserved overlaying Pirania spicules (Figure 6I), where the spicules could easily be mistaken for the chaetae of $M$. burgessensis. Micromitra burgessensis individuals with a full chaetal complement reach a maximum size of $23 \mathrm{~mm}$ in length and $26 \mathrm{~mm}$ in width. Although Pirania varies in size, minimum $6.5 \mathrm{~mm}$ in height and $4 \mathrm{~mm}$ in width (Figure 1F) and maximum $30 \mathrm{~mm}$ in height and $13 \mathrm{~mm}$ in width [90], the size of M. burgessensis and Pirania individuals are largely comparable. There is also a remarkable similarity in the diamond-shaped shell structure of M. burgessensis (though absent in Paterina zenobia) and the rhomboidal texture of the tufts and canals of the sponge wall of Pirania (compare Figure 6F and G).

The prevalence of Micromitra burgessensis individuals attached to Pirania (Additional file 1) suggests the two 
organisms frequently lived in the same ecosystem. Previous analyses of the Burgess Shale community have also demonstrated a close association between the two organisms and that this interaction was constant over time [99]. Consequently, potential brachiopod predators (e.g. Ottoia or Sidneyia) in the Burgess Shale fauna must have also encountered Pirania. The chaetae exhibited by $M$. burgessensis and $P$. zenobia have not been replicated by other fossil or extant brachiopods and long, semi-rigid chaetae are seemingly restricted to the Burgess Shale, where the sponge Pirania is most common. Combined with the close faunal associations of M. burgessensis and Pirania and the size similarities between the spicules of Pirania and the chaetae of M. burgessensis, this raises the possibility that $M$. burgessensis chaetae evolved to mimic characteristics of a co-occurring unpalatable sponge and deter potential predators. This relationship would constitute a form of Batesian mimicry, where palatable species mimic an unpalatable model, obtaining some degree of protection by deceiving predators that have learnt to avoid the unpalatable model $[77,85,86]$. For Batesian mimicry to successfully result in lower mortality rates it is crucial that the unprofitable model is present in the community at high frequency $[77,85,86]$. A greater proportion of models compared with mimics is observed in the Burgess Shale community where Pirania individuals outnumber $M$. burgessensis individuals (253 specimens of Pirania compared to 134 specimens of Micromitra in the Walcott Quarry Member) $[99,100]$. If the model is absent from the community, there is potential that predators will not recognize the mimic as unpalatable and the protection provided by the model could collapse [88]. Pirania is absent from the Burgess Shale community documented from the Raymond Quarry (slightly younger than the Walcott Quarry [90]). Specimens of Ottoia that contain Micromitra valves in their gut are all part of the Raymond Quarry community, with only one possible example of a small M. burgessensis specimen in the gut of an Ottoia from the older Walcott Quarry, where Pirania is present (Vannier [51] Additional file 1: Table S1). While this disparity may be due to variable taphonomic biases that influence abundance levels [100], that this congruence with modern studies exists [88] does further support the possibility that Batesian mimicry explains the uniqueness of the chaetae exhibited by Micromitra burgessensis.

Micromitra burgessensis and Pirania muricata may not be morphologically identical, however examples of the imperfect resemblance between Batesian mimics and their models are widespread [101-103]. For example, many species of hoverflies are generally regarded as Batesian mimics of wasps and bees and yet to the human eye, the resemblance between the organisms is quite crude [101,103,104]. Batesian mimicry is somewhat dependent on the visual capabilities of the predators and mimics will resemble their models in ways that potential predators can perceive $[105,106]$. The morphology of mimics may simply evolve to the extent where the resemblance to their model is sufficient enough to deceive the visual capabilities of the predator [105-107], which may be the case for M. burgessensis.

\section{Spatial competition}

One of the most important resources a brachiopod must compete for is space, a necessary requirement for successful settlement, growth and feeding [25,108]. Substrate space is frequently a limiting resource and, as an immobile component of the hard substratum epifauna, brachiopods have been competing for living space with other epifaunal organisms since the Cambrian. Encrusting sponges and colonial bryozoans are generally considered in modern marine communities to be superior competitors when competing with solitary animals for substrate space [109-111] and the limited passive defenses of living brachiopods make them particularly vulnerable to smothering by other organisms $[25,111]$.

Brachiopods typically struggle to discourage competitors' growth, relying upon their large size, coupled with frequent shell rotation around the pedicle and raising the commissure of their shell off the substrate to impede growth of spatial competitors [112-114]. Brachiopod species tend to be gregarious in shallow water habitats where spatial competition is assumed to be intense and this lifestyle may represent another potential mechanism to exclude competitors, grazers and predators [33,62,114-116]. Brachiopod larvae are commonly documented settling on conspecifics, frequently on the anterior edge of the maternal shell (Figure 5B), leading to the formation of dense 'grape-like' clumps of brachiopod individuals $[45,57,108,113,117]$. This strategy is evident in Burgess Shale specimens (Figures 1I and 2C). In laboratory conditions, the larvae of Laques and Liothyrella preferentially settle on the shells of living conspecifics $[108,117]$ and in some cases conspecific shells even induce the metamorphosis of the larvae brachiopod [115,118]. The stunting and malformation of some individuals growing within these clumps $[57,113]$ are indications that some negative effects of conspecific settlement do exist. However potential advantages of reduced juvenile mortality and excluding competitors and grazers must outweigh these negative effects, given the frequency of these gregarious clumps $[108,117]$. One impressive account of active defense against spatial competitors is the discinid brachiopod Discinisca strigata, that prevents or represses the growth of competitive invertebrates by abrading their tissues and depleting the immediately surrounding water of nutrients [33]. The abrasion is generated by 
the brachiopod closing and rotating its phosphatic valves, resulting in a sweeping motion of its long, robust barbed chaetae (Labarbera [33], Figure three) damaging the tissues of the adjacent bryozoans and encrusting sponges [33].

The soft, muddy Burgess Shale seafloor would have provided limited hard substrates for brachiopods to attach to, including largely biogenic substrates, such as sponges (Figures $1 \mathrm{~F}-\mathrm{J}$ and $2 \mathrm{~K}-\mathrm{M}$ ), other brachiopods (Figure 2C) and disarticulated skeletal elements (Figures $1 \mathrm{~K}$ and $4 \mathrm{~A}$ ). This need to settle on a hard substrates with only limited suitable substrates available presumably resulted in spatial competition among the dominant sessile members of the epifaunal Burgess Shale community. The large majority of attached specimens (Additional file 1) of Micromitra burgessensis and Paterina zenobia display a solitary lifestyle (the only organism attached to that particular substrate) or are conspecific clusters of individuals (Figure 1E, I). There are only three cases (Figures $1 \mathrm{~F}-\mathrm{H}, \mathrm{J}$ ) where $M$. burgessensis individuals share a substratum (Pirania muricata) with another taxon; one with the acrotretid Acrothyra gregaria (Figure 1F), one with the kutorginid Nisusia burgessensis (Figure 1G-H) and one with both an A. gregaria and N. burgessensis (Figure 1J). In all three cases, the brachiopod individuals are positioned on opposite sides of Pirania with the anterior edge of the shell oriented away from the other brachiopod individuals (Figure 1F-J). This positioning suggests that no $M$. burgessensis individuals on the specimens examined would have had the opening of their valves impeded by the presence of A. gregaria or $N$. burgessensis, with appropriate space between the individuals (Figure 4G-H).

In terms of chaetal length relative to shell size, $M$. burgessensis and P. zenobia are most comparable to extant discinids, in particular Discinisca (Figure 5A-B) and Pelagodiscus [119]. Both discinid taxa possess chaetae that commonly exceed the length of the shell by a few millimeters $[33,45,119]$. The musculature of both M. burgessensis and P. zenobia would not have allowed for a discinid-like rotation of the valves $[43,44]$ and there is no evidence of barbs on the chaetae of either paterinate taxa. However, the brachiopods of the Burgess Shale did not have to spatially contend with encrusting sponges and bryozoans [99]. The main competition for attachment space on hard substrata would have been from other brachiopod individuals. The chaetae of $M$. burgessensis and P. zenobia although semi-rigid, would not have been stable enough for brachiopod larvae to settle on, consequently giving the individual a buffer zone, discouraging the larvae of other brachiopods that could have potentially impeded feeding from settling on or close to their shells.

\section{Conclusions}

Determining the functional mechanism of morphological features in fossil taxa is a difficult task, especially if the same features are not directly comparable and not fully understood in extant taxa. The sheer size of the chaetae possessed by both $M$. burgessensis and P. zenobia suggests that they must have held an important functional significance. A protective sensory role has been one of the most commonly proposed hypotheses to explain brachiopod chaetae and there is some evidence from the Burgess Shale to suggest that chaetae acted in this way for Micromitra and Paterina. Brachiopods were prey items in the Burgess Shale and an early sensory warning system would have been beneficial for protection against predators and consequently a sensory role cannot be discounted. That said, it is not clear how effective as a sensory tool the chaetae would have been for predators such as Ottoia and Sidneyia, and there is a distinct lack of smaller scale durophagous predation to support the construction of such elaborate chaetal structures. It is also possible that rather than a pure sensory role, that the substantial increase in brachiopod body size caused by the possession of these long, semi-rigid chaetae impeded ingestion and was a deterrent against predators, such as Ottoia. The arrangement and spacing of chaetae in $M$. burgessensis and P. zenobia provides little support for the chaetae playing a sieving role to obstruct excessive intake of fine particles and the lack of chaetal clustering discounts the chaetae forming a siphon to assist in creating feeding currents. The soft, muddy Burgess Shale seafloor provided limited hard substrata for brachiopods to attach to and the need to settle and, once settled, retain the ability to feed efficiently would likely have been the primary focus of the individual. Creating a chitinous buffer zone to impede larvae of other brachiopods settling on or in the immediate vicinity increases the likelihood of unimpeded growth. The increased competition in response to the lack of suitable substrate in the environment could have driven the emergence of exaggerated adaptations resulting in extreme length of chaetae seen in brachiopods of the Burgess Shale community and represents a plausible interpretation presented herein. An alternative view that the chaetae of $M$. burgessensis chaetae evolved to mimic characteristics of the co-occurring unpalatable sponge, Pirania muricata to deter potential predators, remains speculative, however the remarkable morphological similarities provides a conceivable and justifiable hypothesis. Documentation of brachiopod unbiomineralized anatomy is paramount in our understanding of the evolution and ecology of one of the oldest animal phyla. The functional mechanisms of brachiopod chaetae proposed here delivers a new perspective on their role in early brachiopod taxa and is critical not only to our understanding of the 
ecology of early brachiopod assemblages, but also the benthic dynamics of early Cambrian marine ecosystems.

\section{Methods \\ Material}

This study is based on 282 brachiopod specimens (208 specimens of Micromitra and 74 specimens of Paterina) from the Cambrian (Series 3, Stage 5) Burgess Shale Formation, Yoho National Park, Canada. The examined specimens (Additional file 1) are housed at the Royal Ontario Museum (acronym: ROM), the National Museum of Natural History, Smithsonian Institution (acronym: USNM) and a small selection at the Geological Survey of Canada (acronym: GSC). Extant brachiopod genera (Figure 5) are housed at the Swedish Museum of Natural History (SMNH). The majority of specimens were collected in situ on Fossil Ridge in British Columbia, predominantly from the Greater Phyllopod Bed (WQ and BW) $[99,100]$ and the Raymond Quarry. Some specimens of M. burgessensis and P. zenobia (99 specimens) were collected from talus material above and below the Walcott and Raymond quarries (WT and RT) and come from the Trilobite Beds (ST) and also potentially from the Emerald Lake Oncolite Member [120]. Specimens were photographed under normal and cross-polarized light and wet and dry conditions using a Canon EOS6D digital SLR camera. Scanning electron microscope (SEM) photographs of uncoated specimens (Figure 3) were undertaken using a Zeiss Supra 35 VP microscope.

\section{Additional file}

Additional file 1: Table detailing the material studied, including locality information, collection number, presence or absence of chaetae and the attachment strategy exhibited by individual specimens. Abbreviations: M - Micromitra burgessensis, P - Paterina zenobia, N - Nisusia burgessensis, A - Acrothyra gregaria, C - specimen preserved with identifiable chaetae. The specimens are housed in the Royal Ontario Museum (ROM), Toronto, Canada, the Smithsonian National Museum of Natural History (USNM), Washington DC and three specimens at the Geological Survey of Canada (GSC), Ottawa, Canada.

\section{Competing interests}

The authors declare that they have no competing interests.

\section{Authors' contributions}

All authors directly contributed to the interpretation of fossil specimens. TPT wrote the text with significant input from LCS and all authors. Contributions regarding batesian mimicry were supplied by ZZ and information on modern lophotrochozoan taxa from NNT. TPT conducted the digital photography, SEM imaging and drafted the figures. Material was collected over many field seasons of which JBC was present on a large majority. TPT, $\mathrm{LEH}$ and JBC initially examined the specimens presented herein. All authors read and approved the final manuscript.

\section{Acknowledgements}

Mark Florence (Smithsonian Institution) and Peter Fenton (ROM) for assistance with Smithsonian Institution and Royal Ontario Museum specimens. Miloš Bartol (Uppsala University) for invaluable advice and assistance in imaging techniques. Sabine Stöhr (Swedish Natural History Museum) is thanked for access to the collections at the Department of Zoology, Swedish Natural History Museum. A variety of funding bodies are acknowledged; the Swedish Research Council, Sweden (VR 2009-4395, 2012-1658) to TPT and LEH, a Natural Sciences and Engineering Research Council Discovery Grant (\#341944) to J.-B.C. and the National Natural Science Foundation to ZZ (Grant 41425008). The manuscript benefited from constructive reviews by Nick Butterfield, Roger Thomas and Jean Vannier. This is a Royal Ontario Museum Burgess Shale project number 65 .

\section{Author details}

${ }^{1}$ Department of Earth Sciences, Palaeobiology, Uppsala University, Villavägen 16, SE - 75236 Uppsala, Sweden. ²Department of Palaeobiology, Swedish Museum of Natural History, P.O. Box 50007, SE-104 05 Stockholm, Sweden. ${ }^{3}$ Department of Biological Sciences, Macquarie University, Sydney, NSW 2109, Australia. ${ }^{4}$ Early Life Institute and Department of Geology, State Key Laboratory for Continental Dynamics, Northwest University, Xian 710069, China. ${ }^{5}$ Department of Natural History (Palaeobiology Section), Royal Ontario Museum, 100 Queen's Park, Toronto, Ontario M5S2C6, Canada. ${ }^{6}$ Department of Ecology and Evolutionary Biology, University of Toronto, 25 Willcocks Street, Toronto, Ontario M5S3B2, Canada. ${ }^{7}$ Department of Earth Sciences, University of Toronto, 22 Russell Street, Toronto, Ontario M5S3B1, Canada.

Received: 12 November 2014 Accepted: 23 February 2015

Published online: 13 March 2015

\section{References}

1. Williams A, Carlson SJ, Brunton CHC, Holmer LE, Popov L. A supra-ordinal classification of the Brachiopoda. Philo Trans R Soc Lond B. 1996;351:1171-93.

2. Pelman YL. Early and Middle Cambrian inarticulate brachiopods of the Siberian Platform. Trudy Inst Geol Geo Akad Nauk SSSR Sib Otd. 1977;316:1-168.

3. Topper TP, Holmer LE, Skovsted CB, Brock GA, Balthasar U, Larsson C, et al. The oldest brachiopods from the lower Cambrian of South Australia. Acta Pal Pol. 2013;58:93-109.

4. Zhang Z, Holmer LE. Exceptionally preserved brachiopods from the Chengjiang Lagerstätte (Yunnan, China): Perspectives on the Cambrian explosion of metazoans. Sc Found China. 2013;21:66-80.

5. Holmer LE, Caron JB. A spinose stem group brachiopod with pedicle from the Middle Cambrian Burgess Shale. Acta Zool. 2006;87:273-90.

6. Pettersson Stolk S, Holmer LE, Caron JB. First record of the brachiopod Lingulella waptaensis with pedicle from the Middle Cambrian Burgess Shale. Acta Zool. 2010;91:150-62.

7. Giribet G, Dunn CW, Edgecombe GD, Hejnol A, Martindale MQ, Rouse GW. Assembling the spiralian tree of life. In: Telford MJ, Littlewood DTJ, editors. Animal evolution: genes, genomes, fossils and trees. Oxford: Oxford University Press; 2009. p. 52-64

8. Edgecombe G, Giribet G, Dunn CW, Hejnol A, Kristensen RM, Neves RC, et al. Higher-level metazoan relationships: recent progress and remaining questions. Orga Div Evol. 2011;11:151-72.

9. Merz RA, Woodin SA. Polychaete chaetae: Function, fossils, and phylogeny. Integrat Compar Biol. 2006;46:481-96.

10. Dunn CW, Hejnol A, Matus DQ, Pang K, Browne WE, Smith SA, et al. Broad phylogenomic sampling improves resolution of the animal tree of life. Nature. 2008;452:745-9.

11. Struck TH, Paul C, Hill N, Hartmann S, Hösel C, Kube M, et al. Phylogenomic analyses unravel annelid evolution. Nature. 2011;471:95-8.

12. Rouse GW, Fauchald K. Cladistics and polychaetes. Zool Scripta. 1997;26:139-204

13. Fauchald K, Rouse G. Polychaete systematics: past and present. Zool Scripta. 1997;26:71-138.

14. Butterfield NJ. A reassessment of the enigmatic Burgess Shale fossil Wiwaxia corrugata (Matthew) and its relationship to the polychaete Canadia spinosa Walcott. Paleobiology. 1990;16:287-303.

15. Woodin SA, Merz RA, Thomas FM, Edwards DR, Garcia IL. Chaetae and mechanical function: tools no Metazoan class should be without. Hydrobiol. 2003;496:253-8. 
16. Storch DDV, Welsch DDU. Epitheliomuscular cells in Lingula unguis (Brachiopoda) and Branchiostoma lanceolatum (Acrania). Cell Tiss Res. 1974;154:543-5.

17. Gustus RM, Cloney RA. Ultrastructural Similarities Between Setae of Brachiopods and Polychaetes. Acta Zool. 1972;53:229-33.

18. Orrhage DDL. Light and electron microscope studies of some brachiopod and pogonophoran setae. Zeitschrift für Morphologie der Tiere. 1973;74:253-70

19. Lüter C. Ultrastructure of larval and adult setae of Brachiopoda. Zool Anz. 2000;239:75-90.

20. James MA. Brachiopoda: Internal anatomy, embryology, and development. Micro Anat Invert. 1997;13:297-407.

21. Williams A, James MA, Emig CC, Mackay S, Rhodes MC. Anatomy. In: Kaesler $\mathrm{RL}$, editor. Treatise on invertebrate paleontology, vol. H. Kansas: The Geological Society of America; 1997. p. 7-151.

22. Lüter $C$. Brachiopod larval setae-a key to the phylum's ancestral life cycle? In: Brunton H, Cocks LR, Long S, editors. Brachiopods. London and New York: Taylor and Francis; 2001. p. 46-55.

23. Zakrzewski AC, Suh A, Lüter C. New insights into the larval development of Macandrevia cranium (Müller, 1776)(Brachiopoda: Rhynchonelliformea). Zoologischer Anzeiger-A J Compar Zoo. 2012;251:263-9.

24. Williams A. Distribution of brachiopod assemblages in relation to Ordovician palaeogeography. Spec Pap Pal. 1973;12:241-69.

25. James MA, Ansell AD, Collins MJ, Curry GB, Peck LS, Rhodes MC. Biology of living brachiopods. Advan Mar Bio. 1992;28:175-387.

26. Jin J, Zhan R, Copper P, Caldwell WGE. Epipunctae and phosphatized setae in Late Ordovician plaesiomyid brachiopods from Anticosti Island, eastern Canada. J Info. 2007;81:4.

27. Popov LE, Bassett MG, Holmer LE, Ghobadi Pour M. Early ontogeny and soft tissue preservation in siphonotretide brachiopods: New data from the Cambrian-Ordovician of Iran. Gond Res. 2009;16:151-61.

28. George JD, Southward EC. A comparative study of the setae of Pogonophora and polychaetous Annelida. J Mar Biol Assoc UK. 1973;53:403-24.

29. Lüter C, Bartolomaeus T. The phylogenetic position of Brachiopoda-a comparison of morphological and molecular data. Zool Scripta. 1997;26:245-53.

30. McHugh D. Molecular phylogeny of the Annelida. Can J Zoo. 2000;78:1873-84.

31. Struck TH, Schult N, Kusen T, Hickman E, Bleidorn C, McHugh D, et al. Annelid phylogeny and the status of Sipuncula and Echiura. BMC Evol Biol. 2007;7:57.

32. Rudwick MJS. Living and Fossil Brachiopods. London: Hutchinson and Co.; 1970.

33. Labarbera M. Mechanisms of spatial competition of Discinisca strigata (Inarticulata: Brachiopoda) in the intertidal of Panama. Bio Bull. 1985;168:91-105.

34. Chuang SH. Larval development in Discinisca (inarticulate brachiopod). Am Zool. 1977;17:39-53.

35. Nielsen C. The development of the brachiopod Crania (Neocrania) anomala (OF Müller) and its phylogenetic significance. Acta Zool. 1991;72:7-28.

36. Shiells KAG. Kochiproductus coronus sp. nov. from the Scottish Viséan and a Possible Mechanical Advantage of its Flange Structure. Trans R Soc Edin. 1968;67:477-507

37. Biernat $G$, Williams A. Shell structure of the siphonotretacean Brachiopoda. Palaeontol. 1971;14:423-30

38. Thayer CW, Steele-Petrović HM. Burrowing of the lingulid brachiopod Glottidia pyramidata: its ecologic and paleoecologic significance. Lethaia. 1975:8:209-21.

39. Walcott CD. Cambrian Brachiopoda. United States Geological Survey Monograph. 1912;51, Part 1:1-872, Part 2:1-363.

40. Walcott CD. Cambrian and Ozarkian Brachiopoda. Cambrian geology and palaeontology IV. Smith Misc Coll. 1924;67:477-554.

41. Resser CE. Fourth contribution to nomenclature of Cambrian fossils. Smith Misc Coll. 1938;97:1-43.

42. Topper TP, Holmer LE, Caron JB. Brachiopods hitching a ride: an early case of commensalism in the middle Cambrian Burgess Shale. Sci Rep. 2014;4:6704.

43. Laurie J. The musculature and vascular systems of two species of Cambrian Paterinide (Brachiopoda). BMR J Aus Geol Geophy. 1987;10:261-5.

44. Laurie J. Class Paterinata. In: Kaesler RL, editor. Treatise on invertebrate paleontology, vol. H(2). Kansas: The Geological Society of America; 2000. p. 147-57.
45. Mergl M. Discinid brachiopod life assemblages: Fossil and extant. Bull Geosc. 2010;85:27-38

46. Rudwick MJS. Sensory spines in the Jurassic brachiopod Acanthothiris. Pal. 1965:8:604-17.

47. Hiller $\mathrm{N}$. The development of growth lines on articulate brachiopods. Lethaia. 1988;21:177-88.

48. Zhang Z, Holmer LE, Robson SP, Hu S, Wang X, Wang H. First record of repaired durophagous shell damages in Early Cambrian lingulate brachiopods with preserved pedicles. Pal Pal Pal. 2011;302:206-12.

49. Vannier J, Chen J. Early Cambrian food chain: new evidence from fossil aggregates in the Maotianshan Shale biota, SW China. Palaios. 2005;20:3-26.

50. Skovsted CB, Brock GA, Lindström A, Peel JS, Paterson JR, Fuller MK. Early Cambrian record of failed durophagy and shell repair in an epibenthic mollusc. Biol Letters. 2007;3:314-7.

51. Vannier J. Gut contents as direct indicators for trophic relationships in the Cambrian marine ecosystem. PLoS One. 2012;7:e52200

52. Vannier, J, Lerosey-Aubril, R, Zacai, A: Reconstructing the diet of Cambrian arthropods: A challenge met [abstract] 4th Int. Pal. Congress, 2014, pp. 482

53. Walcott CD. Middle Cambrian Annelids. Cambrian Geology and Paleontology II. Smith Misc Coll. 1911;57:109-44.

54. Walcott CD. Middle Cambrian Merostomata. Cambrian Geology and Paleontology II. Smith Misc Coll. 1911;57:17-40.

55. Rong JY. Cambrian brachiopods. In: Nanjing Institute of Geology, Academia Sinica, Handbook of Palaeontology and Stratigraphy of Southwest China. Beijing, China: Sciences Press; 1974. p. 114-55.

56. Nielsen C. Animal Evolution: Interrelationships of the living phyla. 2nd ed Oxford: Oxford University Press, UK; 2001.

57. Thayer CW. Ecology of living brachiopods. Lophophorates Notes Short Course. 1981:5:110-26

58. Thayer CW, Allmon RA. Unpalatable thecideid brachiopods from Palau: ecological and evolutionary implications. In: MacKinnon DE, Campbell JD, editors. Brachiopods through time. Rotterdam: AA Balkema; 1991. p. 253-60.

59. Peck LS. The tissues of articulate brachiopods and their value to predators. Phil Trans Roy Soc Lon Ser B. 1993;339:17-32.

60. Harper EM, Wharton DS. Boring predation and Mesozoic articulate brachiopods. Pal Pal Pal. 2000;158:15-24.

61. Leighton LR. Predation on brachiopods. In: Kelly PH, Kowalewski N, Hansen TA, editors. Predator-Prey Interactions in the Fossil Record. New York: Plenum/Kluwer Publishers; 2003. p. 215-37.

62. Noble JPA, Logan A, Webb GR. The Recent Terebratulina community in the rock subtidal zone of the Bay of Fundy, Canada. Lethaia. 1976;9:1-17.

63. Witman JD, Cooper RA. Disturbance and contrasting patterns of population structure in the brachiopod Terebratulina septentrionalis (Couthouy) from two subtidal habitats. J Exp Mar Biol Ecol. 1983;73:57-79.

64. Morris SC, Bengtson S. Cambrian predators: possible evidence from boreholes. J Paleontol. 1994;68:1-23.

65. Peel, J.S. Failed predation, commensalism and parasitism on lower Cambrian linguliformean brachiopods. Alcheringa. in press. Doi: 10.1080/ 03115518.2015 .964055

66. Williams A, Carlson SJ, Brunton CHC. Classification. In: Kaesler RL, editor Treatise on invertebrate paleontology, vol. H. Kansas: The Geological Society of America; 2000. p. 1-29.

67. Strathmann R. Function of lateral cilia in suspension feeding of lophophorates (Brachiopoda, Phoronida, Ectoprocta). Mar Biol. 1973;23:129-36.

68. Steele-Petrović HM. An explanation for the tolerance of brachiopods and relative intolerance of filter-feeding bivalves for soft muddy bottoms. J Paleontol. 1975:49:552-6.

69. Thayer CW. Are brachiopods better than bivalves? Mechanisms of turbidity tolerance and their interaction with feeding in articulates. Paleobiology. 1986:12:161-74.

70. Rhodes MC, Thayer CW. Mass extinctions: ecological selectivity and primary production. Geology. 1991;9:877-80

71. Gabbott SE, Zalasiewicz J, Collins D. Sedimentation of the phyllopod bed within the Cambrian Burgess Shale Formation of British Columbia. J Geo Soc. 2008;165:307-18.

72. Gaines RR, Hammarlund EU, Hou X, Qi C, Gabbott SE, Zhao Y, et al. Mechanism for Burgess Shale-type preservation. Proc Natl Acad Sci. 2012:109:5180-4.

73. Baird MJ. The seasonal biology of the brachiopod Liothyrella neozelanica (Thomson, 1918) from Doubtful Sound, New Zealand. University of Otago: PhD thesis; 2012 
74. Schumacher, CF. Essai d'un nouveau systeme des habitations des vers testaces. Copenhagen: L'Imprimerie de Ma. le directeur Schultz; 1817.

75. Villamizar E, Laughlin RA. Fauna associated with the sponges Aplysina archeri and Aplysina lacunosa in a coral reef of the Archipielago de los Roques, National Park, Venezuela. In: Reitner J, Keupp H, editors. Fossil and Recent Sponges. New York: Springer-Verlag; 1992. p. 522-42.

76. Carrera MG. Epizoan-sponge Interactions in the Early Ordovician of the Argentine Precordillera. Palaios. 2000;15:261-72.

77. Fisher RA. The genetical theory of natural selection. London: Oxford University Press; 1930.

78. Robison BH. Shape change behavior by mesopelagic animals. Mar Fresh Behav Physiol. 1999;32:17-25

79. Hanlon RT, Conroy LA, Forsythe JW. Mimicry and foraging behaviour of two tropical sand-flat octopus species off North Sulawesi, Indonesia. Boil J Linn Soc. 2008;93:23-38.

80. Ruxton GD. Sherratt, TN, Speed, M: Avoiding Attack: The Evolutionary Ecology of Crypsis, Warning Signals and Mimicry. Oxford: Oxford University Press, UK; 2004.

81. Randall JE. A review of Mimicry in Marine Fishes. Zool Stud. 2005;44:299-328.

82. Cheney KL. Multiple selective pressures apply to a coral reef fish mimic: a case of Batesian-aggressive mimicry. Proc R So B Biol Sci. 2010;277:1849-55.

83. Cott HB. Adaptive coloration in animals. London, UK: Methuen; 1940.

84. Baliński A. First Colour-Patterned Strophomenide Brachiopod from the Earliest Devonian of Podolia, Ukraine. Acta Pal Pol. 2010;55:695-700.

85. Nur U. Evolutionary rates of models and mimics in Batesian Mimicry. Am Nat. 1970;104:477-86.

86. Lindström L, Alatalo RV, Mappes J. Imperfect Batesian mimicry - the effects of the frequency and the distastefulness of the model. Proc R Soc Lond B. 1997;264:149-53.

87. Joron M, Mallet JLB. Diversity in mimicry: paradox or paradigm. Trends Eco Evol. 1988;13(11):461-6.

88. Pfennig DW, Harcombe WR, Pfennig KS. Frequency-dependent Batesian mimicry. Nature. 2001;410:323-3.

89. Walcott CD. Middle Cambrian Spongiae. Cambrian geology and paleontology IV. Smith Misc Coll. 1920;67:160-217.

90. Rigby JK, Collins D. Sponges of the Middle Cambrian Burgess Shale and Stephen Formations, British Columbia. Toronto: ROM Contributions in Science; 2004.

91. Burns $E$, llan M. Comparison of anti-predatory defenses of Red Sea and Caribbean sponges. II. Physical defense. Mar Ecol Prog Ser. 2003;252:115-23.

92. Wulff $J$. Sponge feeding by Caribbean angelfishes, trunkfishes and filefishes. In: Van Soest RWM, Van Kempen TMG, Breakman JC, editors. Sponges in time and space. Rotterdam: Balkema; 1994. p. 265-71.

93. Todd CD. The ecology of nudibranch molluscs. Oceanogr. Mar Biol Annu Rev. 1981;19:141-234.

94. Meylan A. Spongivory in hawksbill turtles: a diet of glass. Science. 1988;239:393-5

95. Bjorndal KA. Digestibility of the sponge Chondrilla nucula in the green turtle, Chelonia mydas. Bull Mar Sci. 1990;47:567-70.

96. Dunne JA, Williams RJ, Martinez ND, Wood RA, Erwin DH. Compilation and network analyses of Cambrian food webs. PLoS Biol. 2008;6(4):e102.

97. Vannier, J, Liu, J, Lerosey-Aubril, R, Vinther, J, Daley, AC: Sophisticated digestive systems in early arthropods. Nature 5. doi:10.1038/ncomms4641.

98. Botting JP, Muir LA, Xiao S, Li X, LIN JP. Evidence for spicule homology in calcareous and siliceous sponges: biminerallic spicules in Lenica sp. from the Early Cambrian of South China. Lethaia. 2012;45:463-75.

99. Caron JB, Jackson DA. Paleoecology of the greater phyllopod bed community, Burgess Shale. Pal Pal Pal. 2008;258:222-56.

100. Caron JB, Jackson DA. Taphonomy of the greater phyllopod bed community, Burgess Shale. Palaios. 2006;21:451-65.

101. Sherratt TN. The evolution of imperfect mimicry. Behav Ecol. 2002;13:821-6.

102. Chittka L, Osorio D. Cognitive dimensions of predator responses to imperfect mimicry. PLoS Biol. 2007;5(12):e339.

103. Penney HD, Hassal C, Skevington JH, Abbott KR, Sherrat TN. A comparative analysis of the evolution of imperfect mimicry. Nature. 2012;483:461-4.

104. Edmunds M. Why are there good and poor mimics? Biol J Linn Soc. 2000;70:459-66.

105. Kikuchi DW, Pfennig DW. Predator cognition permits imperfect coral snake mimicry. Am Nat. 2010;176:830-4.

106. Kraemer AC, Adams DC. Predator Perception of Batesian Mimicry and Conspicuousness in a Salamander. Evolution. 2014;68:1197-206.
107. Cheney KL, Marshall NJ. Mimicry in coral reef fish: how accurate is this deception in terms of color and luminance? Behav Ecol. 2009;20:459-68.

108. Peck LS, Meidlinger K, Tyler PA. Development and settlement characteristics of the Antarctic brachiopod Liothyrella uva (Broderip 1833). In: Brunton $\mathrm{H}$, Cocks LR, Long S, editors. Brachiopods. London and New York: Taylor and Francis; 2001. p. 80-90.

109. Jackson JBC. Competition on marine hard substrata: the adaptive significance of solitary and colonial strategies. Am Nat. 1977;111:743-67.

110. Buss LW. Group living, competition, and the evolution of cooperation in a sessile invertebrate. Science. 1981;213:1012-4.

111. Taylor PD, Wilson MA. Palaeoecology and evolution of marine hard substrate communities. Earth Sci Rev. 2003;62:1-103.

112. Jackson JB, Goreau TF, Hartman WD. Recent brachiopod-coralline sponge communities and their paleoecological significance. Science. 1971;173:623-5.

113. Doherty PJ. A Demographic study of a subtidal population of the New Zealand articulate brachiopod Terebratella inconspicua. Mar Biol. 1979;52:331-42.

114. Thayer CW. Size-frequency and population structure of brachiopods. Pal Pal Pal. 1975;17:139-48.

115. Percival E. A contribution to the life-history of the brachiopod Tegulorhynchia nigricans. Quar J Micro Sci. 1960;3:439-57.

116. Noble JPA, Logan A. Size-frequency distributions and taphonomy of brachiopods: a recent model. Pal Pal Pal. 1981;36:87-105.

117. Pennington JT, Tamburri MN, Barry JP. Development, temperature tolerance, and settlement preference of embryos and larvae of the articulate brachiopod Laqueus californianus. Biol Bull. 1999;196:245-56.

118. Freeman G. Metamorphosis in the brachiopod Terebratalia: evidence for a role of calcium channel function and the dissociation of shell formation from settlement. Biol Bull. 1993;184:15-24.

119. Lee DE. Cenozoic and recent inarticulate brachiopods of New Zealand: Discinisca, Pelagodiscus and Neocrania. J R Soc NZL. 1987;17:49-72.

120. Fletcher T, Collins D. The Middle Cambrian Burgess Shale and its relationship to the Stephen Formation in the southern Canadian Rocky Mountains. Can J Earth Sci. 1998;35:413-36.

\section{Submit your next manuscript to BioMed Central and take full advantage of:}

- Convenient online submission

- Thorough peer review

- No space constraints or color figure charges

- Immediate publication on acceptance

- Inclusion in PubMed, CAS, Scopus and Google Scholar

- Research which is freely available for redistribution

Submit your manuscript at www.biomedcentral.com/submit 